\title{
PEMBELAJARAN MATEMATIKA DENGAN PENDEKATAN MULTIPLE INTELLIGENCES UNTUK SISWA SD/MI DI BANTUL
}

\author{
Luluk Mauluah, Endang Sulistyowati dan \\ Mohamad Agung Rokhimawan \\ Universitas Islam Negeri Sunan Kalijaga \\ Email: rokhimawan78@gmail.com
}

\begin{abstract}
Abstrak
Pembelajaran matematika merupakan salah satu pembelajaran yang menjadi momok bagi siswa. Dalam perkembangannya, pembelajaran matematika terus menerus mengalami perkembangan yang pesat. Mulai dari teori belajar, pengembangan strategi, metode maupun produksi alat peraga semakin beragam. Tetapi hal ini belum selaras dengan implementasi pada tataran realita terutama untuk siswa Sekolah Dasar maupun Madrasah Ibtidaiyah. Masih banyak permasalahan yang terjadi pada pembelajaran matematika madrasah maupun pada siswa. Penelitian ini bertujuan untuk mengetahui desain pembelajaran matematika dengan pendekatan multiple intelligences untuk siswa SD/MI di Bantul dan mengetahui respon siswa terhadap pelaksanaan pembelajaran tersebut. Berdasarkan hasil penelitian dapat diketahui bahwa desain pembelajaran matematika dengan pendekatan multiple intelligences untuk siswa SD/MI di Bantul dapat meningkatkan respon siswa terhadap pembelajaran matematika, yakni lebih dari $85 \%$ yaitu 35 dari 40 peserta sangat menyukai pelaksanaan pembelajaran matematika berbasis multiple intelligences dengan peraga, permainan dan aktivitas serta adventure.
\end{abstract}

Kata kunci: Kecerdasan, majemuk, matematika

\begin{abstract}
Learning mathematics is one that is a scourge of learning for students. In the process, the learning of mathematics continue to experience rapid growth. Ranging from learning theory, strategy development, and production methods increasingly diverse props. But it is not yet aligned with the implementation at the level of reality, especially for students from elementary schools and Islamic Elementary School. There are still many problems that occur in the madrasah and learning of mathematics in students. This study aims to determine the design of mathematics learning with multiple intelligences approach for students SD/MI in Bantul and knowing the students' response to the implementation of the learning. Based on the results of this research is that the design of mathematics learning with the approach of multiple intelligences for students SD/MI in Bantul can improve students' response to the learning of mathematics, ie more than $85 \%$, ie 35 out of 40 participants really liked the implementation of the mathematicsbased multiple intelligences with props, games and activity and adventure.
\end{abstract}

Keywords: intelligence, multiple, mathematics 


\section{A. Pendahuluan}

Pembelajaran matematika terus menerus mengalami perkembangan yang pesat. Mulai dari teori belajar, pengembangan strategi, metode maupun produksi alat peraga semakin beragam. Tetapi hal ini belum selaras dengan implementasi pada tataran realita terutama untuk siswa Sekolah Dasar maupun Madrasah Ibtidaiyah. Masih banyak permasalahan yang terjadi pada pembelajaran matematika madrasah maupun pada siswa.

Walaupun minat sudah cukup tinggi terhadap pembelajaran matematika (sesuai wawancara dengan Kepala MI Diponegoro Bantul pada hari Senin, 5 Januari 2015 dan observasi kelas serta wawancara dengan para peserta didik pada hari Senin 9 Februari 2015), tetapi prestasi belum tercapai dengan optimal. Terbukti dengan prestasi nilai UN Matematika dan mata pelajaran lain tahun 2012/2013 berdasar pengumuman di internet yaitu: Rata-rata hasil ujian nasional per mata pelajaran di tingkat provinsi DIY, yaitu Bahasa Indonesia 8,15, Matematika7,00 dan IPA7,48.Di Provinsi DIY, ada 946 siswa yang meraih nilai sempurna untuk mata pelajaran matematika, sedang untuk Bahasa Indonesia dan IPA masing-masing 46 dan 24 siswa. Rekapan sementara dari hasil kelulusan tercatat, rata-rata total nilai akhir jenjang SD/MI, Kota Yogyakarta masih meraih nilai terbaik di DIY yaitu dengan rata-rata 23,62, Kabupaten Bantul 23,50, Kabupaten Kulon Progo 23,40, Kabupaten Sleman 23,28, dan Kabupaten Gunung Kidul 22,53. Sedangkan rata-rata nilai total di DIY adalah sekitar 23,26.

Dari data tersebut nampak bahwa dengan sifat khas matematika, nilai sempurna dapat teraih dengan peluang yang lebih tinggi dibanding mata pelajaran yang lain, tetapi ternyata nilai rata-ratanya masih terendah dibanding nilai rata-rata mata pelajaran yang lain. Dan terlihat juga bahwa kabupaten Bantul masuk peringkat 2 di provinsi DIY, sehingga hal ini dapat menjadi pendorong siswa-siswa sekolah dasar atau madrasah-madrasah di Bantul juga dapat mencapai prestasi yang selaras dengan peringkat tersebut. Pada kenyataannya, berdasar update (pemutakhiran) data pada tanggal 2 Juli 2014, MI Diponegoro memperoleh peringkat ketiga hasil UN di kecamatan Pajangan. Tentu prestasi ini masih terus dapat didorong untuk ditingkatkan. 
Walaupun upaya perbaikan terus menerus dilakukan, teori belajar matematika terus berkembang, strategi pembelajaran semakin beragam tetapi masih banyak siswa yang takut maupun tidak suka dengan matematika. Yang perlu menjadi kajian adalah, masih ada guru yang belum bekerja secara maksimal, masih memahami keadaan peserta didik secara klasikal, belum memperhatikan bahwa siswa mempunyai keunikan sendiri-sendiri. Semiawan ${ }^{1}$ mengemukakan bahwa berbagai inovasi, kreativitas, divergensi berpikir, dan originalitas tidak terintegrasi dalam sistem pembelajaran. Hal ini perlu menjadi perhatian khusus bagi guru maupun dosen untuk tidak berputus asa mengupayakan yang terbaik, memfasilitasi pembelajaran dengan strategi yang mutakhir, sesuai perkembangan teori belajar, tidak mengabaikan keunikan peserta didik, khususnya di bidang matematika.

Teori Multiple Intelligences yang dikembangkan oleh Howard Gardner secara resmi diperkenalkan tahun 1983 melalui bukunya Frames of Mind yang kemudian direvisi dengan Intelligence Reframed tahun 19992. Perkembangan kajian multiple intelligences ini membawa kepada kesadaran baru, bahwa manusia sebagai makhluk Tuhan diciptakan dalam keberagaman, dan hendaknya menerima ini sebagai karunia yang dapat menjadi potensi positif untuk saling mensupport, bukan sebagai potensi perbedaaan untuk saling bersikap menang sendiri.

Teori multiple intelligences yang menghargai kecerdasan dari berbagai sisi ini, dapat dikembangkan dalam pembelajaran matematika, untuk mendorong siswa yang tidak menyukai matematika tetap nyaman belajar matematika. Bahkan dapat mendorong kecerdasan di luar kecerdasan logis-matematis, misalnya kecerdasan bahasa, musikal, intrapersonal untuk tetap berkembang.Implikasi baiknya adalah, selain pembelajaran matematika menjadi lebih menarik, kecerdasankecerdasan lain dapat ditumbuhkan, juga dapat memberikan sumbangan dalam membangun karakter mahasiswa.

\footnotetext{
${ }^{1}$ Muhammad Yaumi, Pembelajaran Berbasis Multiple Intelligence ( Jakarta: Dian Rakyat, 2012) hal :5

${ }^{2}$ Ibid, hal: iii
} 


\section{B. Pembelajaran Matematika SD/MI}

Cagne dan Biggs menyatakan bahwa pembelajaran adalah rangkaian peristiwa/kejadian yang mempengaruhi siswa sedemikian rupa sehingga proses belajarnya dapat berlangsung dengan mudah. Jadi pembelajaran adalah suatu aktivitas yang disengaja untuk memodifikasi berbagai kondisi yang diarahkan untuk tercapainya tujuan, yaitu tujuan kurikulum. ${ }^{3}$ Pembelajaran dipandang sebagai suatu sistem, di dalamnya melibatkan berbagai komponen. Paling tidak terdapat empat komponen dalam pembelajaran, yaitu: tujuan pembelajaran, meteri/bahan pengajaran, metode dan alat yang digunakan, dan penilaian 4 .

Secara etimologi matematika berarti ilmu pengetahuan yang diperoleh dengan bernalar. Matematika mempunyai akar kata mathema yang berarti pengetahuan atau ilmu. Menurut Elea Tinggih, mateamatika berarti ilmu pengetahuan yang diperoleh dengan penalaran ${ }^{5}$. Karakteristik matematika sebagai ilmu deduktif tidak menerima generalisasi berdasarkan pengamatan (induktif ), tetapi harus berdasarkan pembuktian logis 6 .

Jadi pembelajaran matematika adalah aktivitas terdiri dari 4 komponen untuk mencapai tujuan yang mengkaji ilmu tentang penalaran sebagai alat/simbol dan juga seni yang dapat digunakan untuk membantu manusia memahami dan mengetahui masalah sosial, ekonomi dan alam.

\section{Pembelajaran Matematika yang Menyenangkan}

Menurut Zulkifli, usia anak SD/MI di Indonesia pada umumnya berkisar antara 6-12 tahun. Dalam psikologi perkembangan, rentang usia tersebut lazimnya disebut sebagai masa anak (middle and late childhood) yakni suatu fase antara masa kanak-kanak (early childhood) dan masa remaja (adolescence). ${ }^{7}$ Teori kognitif yang dikemukakan oleh Piaget menyatakan bahwa masa ini termasuk dalam fase operasional

\footnotetext{
${ }^{3}$ Tengku Zahara Djafar (2001), Kontribusi Strategi Pembelajaran Terhadap Hasil Belajar. Jakarta:Balitbang Depdiknas; hal 2

${ }^{4}$ Nana Sudjana .(1989) . Teknologi Pengajaran. Bandung: Sinar Ilmu; hal 30

${ }^{5}$ Erman Suherman dkk, strategi Pembelajaran Matematika Kontemporer (Bandung, UPI: 2003)hal 15-16

${ }^{6}$ Ibid, hal 18

${ }^{7}$ Zulkifli L. Psikologi Perkembangan. (Bandung: Remaja Rosda Karya, 2005), hal. 21.
} 
konkrit, dimana aspek berfikir siswa cenderung pada hal-hal yang kongkret $^{8}$. Untuk itu diperlukan peraga dan permainan sehingga pembelajaran menjadi menyenangkan. Pendekatan multiple intelligences membuka berbagai kemungkinan pembelajaran dilakukan dengan disajikan berbasis seni/art maupun musikal sehingga metode dapat lebih bervariasi.

\section{Pendekatan Multiple Intelligences}

Berbagai pandangan yang memandang kecerdasan pada ruang lingkup yang terbatas tersebut mendorong Gardner untuk menyampaikan gagasan cemerlangnya tentang multiple intelligences (kecerdasan jamak, kecerdasan ganda). Howard Gardner dalam bukunya Frames of Mind secara brilian menjelaskan 8 kecerdasan yang dapat digunakan untuk mengukur kecerdasan anak. Ke delapan kecerdasan tersebut adalah: kecerdasan kemampuan logika dan matematika, musik, kinestetik jasmani, linguistik, spasial, antarpribadi (interpersonal), intrapribadi (intrapersonal) dan naturalis ${ }^{9}$ Dan tahun 2002 Colin Rose dan Nicholl menyampaikan ada tambahan kecerdasan ke 9 yaitu kecerdasan spiritual/eksistensial ${ }^{10}$.

Untuk melejitkan kemampuan setiap siswa, perlu dipahami ciri-ciri yang dimiliki seseorang dalam hal 9 kecerdasan majemuknya yaitu11:

1) Kecerdasan linguistik: kemampuan menggunakan kata-kata secara efektif, secara lisan maupun tertulis.

2) Kecerdasan logis-matematis: kemampuan seseorang yang berkenaan dengan rangkaian alasan, mengenal pola-pola dan keteraturan ${ }^{12}$

3) Kecerdasan visual-spasial: kemampuan berpikir seseorang dalam hal gambar dan yang berkenaaan dengan ruang dan tempat atau 3 dimensi ${ }^{13}$

\footnotetext{
${ }^{8}$ Ibid., hal. 19.

${ }^{9}$ Thomas Armstrong, Setiap anak cerdas ( Panduan membantu anak belajar dengan memanfaatkan multiple intelligence), USA: ASCD: 2005; hal 18

${ }^{10}$ Colin Rose dan Malcolm J. Nicholl, Accelerated Learning for the $21^{\text {st }}$ century; Cara Belajar Cepat abad 21 ( Bandung, Nuansa: 2002) hal. 60

${ }^{11}$ Thomas Armstrong, Setiap anak cerdas ( Panduan membantu anak belajar dengan memanfaatkan multiple intelligence), USA: ASCD: 2005; hal 22-40

${ }^{12}$ Kezar, Theory of Multiple Intelligences: Implication for Hegher Education, Innovative Education, vol 26, No 2, Winter: 2001
} 
4) Kecerdasan jasmaniah-kinestetik: kemampuan untuk menggunakan seluruh tubuh dalam mengekspresikan ide, perasaan, dan menggunakan tangan untuk menghasilkan atau mentransformasikan sesuatu ${ }^{14}$.

5) Kecerdasan berirama-musik: kemampuan untuk menikmati, mengamati, membedakan, mengarang, dan membentuk serta mengekspresikan musik.

6) Kecerdasan intrapersonal: kemampuan memahami diri sendiri dan bertindak berdasar pemahaman tersebut ${ }^{15}$.

7) Kecerdasan interpersonal: kemampuan memahami perilaku, sikap dan pikiran orang lain ${ }^{16}$.

8) Kecerdasan naturalistik: kecerdasan untuk mengenali, membedakan, mengungkapkan, dan membuat kategori terhadap apa yang dijumpai di alam lingkungan.

9) Kecerdasan eksistensial-spiritual: kapasitas hidup manusia yang bersumber dari hati yang dalam yang terilhami dalam bentuk kodrat untuk dikembangkan dan ditumbuhkan dalam mengatasi kesulitan hidup ${ }^{17}$

\section{E. Metode Penelitian}

Penelitian ini merupakan penelitian kualitatif yang berupaya untuk melihat pembelajaran matematika dengan pendekatan multiple intelligences untuk siswa SD/MI di Bantul. Teknik pengumpulan data dalam penelitian ini dengan menggunakan dokumentasi, observasi, wawancara, dan angket.

\footnotetext{
${ }^{13}$ Sonawat and Gogri, Multiple Intelligences for Preschool Children; Mumbai:MultiTech Publishing co ( 2008)

${ }^{14}$ Muhammad Yaumi,Pembelajaran Berbasis Multiple Intelligences ( Jakarta: Dian Rakyat, 2012) hal. 17

15 Ibid, hal 20

${ }^{16}$ Ibid, hal 21

${ }^{17}$ M. Yaumi, hal. 25
} 


\section{F. Hasil penelitian dan pembahasan}

a. Desain Pembelajaran Matematika Berbasis Multiple Intelligences

Desain pembelajaran matematika dengan pendekatan multiple intelligences terlaksana sebagai berikut:

a. Pertemuan ke 1,2,5,8, 9, 11, 12, 16, 19 dan 20 diampu oleh ibu Luluk Mauluah dan pertemuan 2,4,6,7,10,13,14,15, 17 dan 18 diampu oleh ibu Endang Sulistyowati

b. Pertemuan ke 16 berupa kegiatan Math Adventure to Adisucipto Airport

c. Pertemuan ke 20 berupa kegiatan Math Adventure to Jakarta by Plane and Train

b. Aspek kecerdasan majemuk yang digunakan dalam penelitian pengabdian

Berdasar pelaksanaan pembelajaran, aspek-aspek kecerdasan yang muncul dan terlibat antara lain adalah: kecerdasan interpersonl berdasar kerja kelompok. Kecerdasan visual dan spasial muncul saat menggunakan peraga matematika berbagai bentuk berbagai warna. Kecerdasan musikal muncul saat bermain klothekan KPK dan bernyanyi matematika. Kecerdasan kinestetik muncul saat bermain air, bersepeda, berlari maupun berjalan saat mempelajari kecepatan dan volume.

Deskripsi Pelaksanaan Pembelajaran

\begin{tabular}{|l|l|l|l|l|}
\hline No & Materi & $\begin{array}{l}\text { Aspek } \\
\text { Kecerdasan }\end{array}$ & $\begin{array}{l}\text { Alat dan } \\
\text { Bahan }\end{array}$ & Deskripsi \\
\hline 1 & Pecahan & $\begin{array}{l}\text { Natural, } \\
\text { interpersonal }\end{array}$ & $\begin{array}{l}\text { Buah- } \\
\text { buahan, } \\
\text { pisau }\end{array}$ & $\begin{array}{l}\text { Peserta } \\
\text { mengenal } \\
\text { buah-buahan } \\
\text { yang tidak ada } \\
\text { di daerahnya: } \\
\text { plum, kiwi }\end{array}$ \\
\hline 2 & $\begin{array}{l}\text { Lagu, yel, } \\
\text { penjumla } \\
\text { han berulang }\end{array}$ & $\begin{array}{l}\text { Musikal, } \\
\text { interpersonal }\end{array}$ & $\begin{array}{l}\text { Baki, cup } \\
\text { kue, seral, } \\
\text { sendok, } \\
\text { kartu } \\
\text { perkalian }\end{array}$ & $\begin{array}{l}\text { Peserta diberi } \\
\text { contoh lagu } \\
\text { operasi hitung } \\
\text { campur. Lalu } \\
\text { mereka } \\
\text { menyanyikan } \\
\text { lagu kemudian } \\
\text { membuat yel } \\
\text { secara }\end{array}$ \\
\hline
\end{tabular}

70 MAGISTRA - Volume 6 Nomor 2 Oktober 2015 


\begin{tabular}{|c|c|c|c|c|}
\hline & & & & $\begin{array}{l}\text { berkelom } \\
\text { pok. } \\
\text { Penjumlahan } \\
\text { berulang } \\
\text { dilakukan } \\
\text { dengan contoh } \\
3 \times 2=3 \text { wadah } \\
\text { masing-masing } \\
\text { diisi } 2 \text { keping. }\end{array}$ \\
\hline 3 & $\begin{array}{l}\text { KPK,FPB, } \\
\text { pengumu } \\
\text { man akan } \\
\text { ada hadiah } \\
\text { tiket } \\
\text { pesawat }\end{array}$ & Musikal & $\begin{array}{l}\text { Alat-alat } \\
\text { klothekan, } \\
\text { power } \\
\text { point } \\
\text { motivasi }\end{array}$ & $\begin{array}{l}\text { Peserta } \\
\text { memukul } \\
\text { alatnya sesuai } \\
\text { detik yang } \\
\text { diminta, kapan } \\
\text { bersamaan } \\
\text { itulah KPK nya. } \\
\text { Motivasi: } \\
\text { diberikan } \\
\text { pengumuman: } \\
\text { pada akhir } \\
\text { program akan } \\
\text { dipilih } 2 \\
\text { peserta terbaik } \\
\text { untuk naik } \\
\text { pesawat ke } \\
\text { Jakarta dan } \\
\text { pulang naik } \\
\text { kereta }\end{array}$ \\
\hline 4 & $\begin{array}{l}\text { Operasi } \\
\text { hitung } \\
\text { campur }\end{array}$ & Natural & $\begin{array}{l}\text { Pattern } \\
\text { block, } 5 \text { set } \\
\text { kartu remi, } \\
5 \text { set dadu } \\
\text { modifika } \\
\text { si, papan } \\
\text { perkalian } \\
\text { dan } \\
\text { penjumlah } \\
\text { an }\end{array}$ & $\begin{array}{l}\text { Melakukan } \\
\text { permainan } \\
\text { berbagai } \\
\text { macam operasi } \\
\text { hitung } \\
\text { campuran } \\
\text { dengan } \\
\text { berbagai } \\
\text { peraga }\end{array}$ \\
\hline 5 & $\begin{array}{l}\text { Geometri } \\
\text { pengukuran: } \\
\text { baku/tak }\end{array}$ & $\begin{array}{l}\text { Kinestetik, } \\
\text { natural }\end{array}$ & $\begin{array}{l}\text { Penggaris } \\
1 \mathrm{~m} \text { dn } 30 \\
\mathrm{~cm},\end{array}$ & $\begin{array}{l}\text { Peserta } \\
\text { praktek } \\
\text { mengukur }\end{array}$ \\
\hline
\end{tabular}

71 MAGISTRA - Volume 6 Nomor 2 Oktober 2015 


\begin{tabular}{|c|c|c|c|c|}
\hline & $\begin{array}{l}\text { baku, luas } \\
\text { dan keliling, } \\
\text { jaring-jaring }\end{array}$ & & $\begin{array}{l}\text { bangun } \\
\text { datar, } \\
\text { potongan } \\
\text { kertas } \\
\text { warna, } \\
\text { selotip, } \\
\text { jaring- } \\
\text { jaring }\end{array}$ & $\begin{array}{l}\text { panjang, lebar, } \\
\text { luas dan } \\
\text { keliling. } \\
\text { Praktek } \\
\text { membuat } \\
\text { jaring-jaring } \\
\text { dari bangun } \\
\text { datar, dan } \\
\text { praktek } \\
\text { membuat } \\
\text { bangun ruang } \\
\text { dari jaring- } \\
\text { jaring }\end{array}$ \\
\hline 6 & $\begin{array}{l}\text { Sudut dan } \\
\text { arah mata } \\
\text { angin }\end{array}$ & Musikal, spsial & $\begin{array}{l}\text { Busur } \\
\text { derajat, } \\
\text { kain } \\
\text { penutup } \\
\text { muka, } \\
\text { jangka } \\
\text { /piring } \\
\text { pembuat } \\
\text { lingkaran }\end{array}$ & $\begin{array}{l}\text { Bermain } \\
\text { tersesat di } \\
\text { hutan, } \\
\text { menyanyi lagu } \\
\text { timur-tenggara }\end{array}$ \\
\hline 7 & $\begin{array}{l}\text { Statistika } \\
\text { sederhana, } \\
\text { angket }\end{array}$ & Intrapersonal & $\begin{array}{l}\text { Papan data } \\
\text { tinggi, } \\
\text { berat } \\
\text { badan, } \\
\text { warna } \\
\text { kesukaan, } \\
\text { permen, } \\
\text { kalkulator }\end{array}$ & $\begin{array}{l}\text { Peserta } \\
\text { praktek } \\
\text { mengumpul- } \\
\text { kan data tinggi, } \\
\text { berat badan, } \\
\text { warna } \\
\text { kesukaan, } \\
\text { permen } \\
\text { kesukaan }\end{array}$ \\
\hline 8 & $\begin{array}{l}\text { Math } \\
\text { adventure to } \\
\text { Adi sucipto }\end{array}$ & $\begin{array}{l}\text { Interpersonal, } \\
\text { logis } \\
\text { matematis, } \\
\text { spasial, natural }\end{array}$ & $\begin{array}{l}\text { Surat } \\
\text { pengantar } \\
\text { kunjun } \\
\text { gan ke } \\
\text { airport, } \\
\text { report } \\
\text { book, } \\
\text { lembar } \\
\text { observasi, } \\
\text { papan }\end{array}$ & $\begin{array}{l}\text { Peserta dibagi } \\
\text { perkelompok } \\
\text { perpen- } \\
\text { damping } \\
\text { menuju pos- } \\
\text { pos : money } \\
\text { changer dan } \\
\text { informasi, } \\
\text { ruang pandang, } \\
\text { secara }\end{array}$ \\
\hline
\end{tabular}

72 MAGISTRA - Volume 6 Nomor 2 Oktober 2015 


\begin{tabular}{|c|c|c|c|c|}
\hline & & & $\begin{array}{l}\text { eksplorasi, } \\
\text { manual } \\
\text { acara }\end{array}$ & bergantian \\
\hline 9 & $\begin{array}{l}\text { Volume, } \\
\text { kecepatan }\end{array}$ & $\begin{array}{l}\text { Kinestetis, } \\
\text { natural }\end{array}$ & $\begin{array}{l}\text { Penggaris, } \\
\text { kalkulator, } \\
\text { stopwa } \\
\text { tch, gelas } \\
\text { ukur, } \\
\text { cairan } \\
\text { warna, } \\
\text { beras }\end{array}$ & $\begin{array}{l}\text { Peserta } \\
\text { menakar } \\
\text { dengan } \\
\text { berbagai gelas } \\
\text { ukur. Berenang } \\
\text { dan mengukur } \\
\text { volume air } \\
\text { kolam. Berlari, } \\
\text { bersepeda dan } \\
\text { berjalan } \\
\text { dihitung waktu } \\
\text { tempuhnya }\end{array}$ \\
\hline 10 & $\begin{array}{l}\text { Math } \\
\text { adventure to } \\
\text { Jakarta by } \\
\text { plane and } \\
\text { train }\end{array}$ & $\begin{array}{l}\text { Interpersonal, } \\
\text { intrapersonal, } \\
\text { logis matematis }\end{array}$ & $\begin{array}{l}\text { Busur, } \\
\text { penggaris, } \\
\text { selotip, } \\
\text { kompas, } \\
\text { LKS, alat } \\
\text { travelling }\end{array}$ & $\begin{array}{l}\text { Berangkat } \\
\text { subuh ke } \\
\text { Jakarta dengan } \\
\text { pesawat lalu } \\
\text { eksplorasi } \\
\text { bandara Soeta, } \\
\text { MK, museum } \\
\text { Nasional, } \\
\text { Keliling dengan } \\
\text { bus tingkat, } \\
\text { Istiqlal dan } \\
\text { Monas }\end{array}$ \\
\hline 11 & $\begin{array}{l}\text { Mainan ular } \\
\text { angka }\end{array}$ & $\begin{array}{l}\text { Logis } \\
\text { matematis, } \\
\text { natural }\end{array}$ & $\begin{array}{l}\text { Papan } \\
\text { angka } \\
\text { badan ular, } \\
3 \text { dadu }\end{array}$ & $\begin{array}{l}\text { Kesalahan yang } \\
\text { dilakukan } \\
\text { adalah belum } \\
\text { urut } \\
\text { bilangannya } \\
\text { dari yang } \\
\text { terkecil ke yang } \\
\text { terbesar }\end{array}$ \\
\hline 12 & Tangram & Natural & $\begin{array}{l}15 \text { set } \\
\text { tangram }\end{array}$ & $\begin{array}{l}\text { Membuat } \\
\text { bentuk bangun } \\
\text { datar baru dari } \\
\text { beberapa } \\
\text { keping tangram } \\
\text { untuk melatih }\end{array}$ \\
\hline
\end{tabular}

73 MAGISTRA - Volume 6 Nomor 2 Oktober 2015 


\begin{tabular}{|c|c|c|c|c|}
\hline & & & & $\begin{array}{l}\text { kepekaan } \\
\text { geometri dan } \\
\text { kreatifitas dan } \\
\text { imajinasi } \\
\text { menyusun } \\
\text { bentuk baru }\end{array}$ \\
\hline 13 & Sudoku & $\begin{array}{l}\text { Logis } \\
\text { matematis }\end{array}$ & $\begin{array}{l}\text { Papan } \\
\text { sudoku, } \\
\text { guntingan } \\
\text { angka }\end{array}$ & $\begin{array}{l}\text { Anak } \\
\text { perempuan } \\
\text { lebih telaten } \\
\text { dibanding anak } \\
\text { laki-laki }\end{array}$ \\
\hline 14 & Kurva & Logis, natural & $\begin{array}{l}\text { Papan } \\
\text { angka, } \\
\text { spidol }\end{array}$ & $\begin{array}{l}\text { Gabungan dari } \\
\text { kecerdasan } \\
\text { bilangan, } \\
\text { motorik halus } \\
\text { dan pola }\end{array}$ \\
\hline 15 & Titik berat & $\begin{array}{l}\text { natural, } \\
\text { kinestetis, }\end{array}$ & $\begin{array}{l}\text { Kertas } \\
\text { bangun } \\
\text { datar, } \\
\text { penggaris, } \\
\text { benang, } \\
\text { manik- } \\
\text { manik }\end{array}$ & $\begin{array}{l}\text { Menguji } \\
\text { ketepatan } \\
\text { pengukuran } \\
\text { titik tengah, } \\
\text { sehingga } \\
\text { rangkaian } \\
\text { hiasan yang } \\
\text { disusun tepat } \\
\text { seimbang }\end{array}$ \\
\hline 16 & Aljabar & Kinestetis & $\begin{array}{l}\text { Timban } \\
\text { gan, } \\
\text { benda- } \\
\text { benda } \\
\text { berbagai } \\
\text { bentuk } \\
\text { dan warna }\end{array}$ & $\begin{array}{l}\text { Melatih } \\
\text { menaksir berat, } \\
\text { melatih } \\
\text { ketelitian dan } \\
\text { melatih operasi } \\
\text { hitung } \\
\text { penjumlahan } \\
\text { dan perkalian }\end{array}$ \\
\hline 17 & $\begin{array}{l}\text { Bangun } \\
\text { datar/teka } \\
\text { teki bil }\end{array}$ & Natural, spasial & $\begin{array}{l}\text { Kertas } \\
\text { gambar, } \\
\text { penggaris, } \\
\text { spidol }\end{array}$ & $\begin{array}{l}\text { Membuat } \\
\text { gambar } \\
\text { pemandangan } \\
\text { berdasar } \\
\text { bangun datar } \\
\text { yang diperoleh } \\
\text { dan } \\
\text { mengurutkan } \\
\end{array}$ \\
\hline
\end{tabular}

74 MAGISTRA - Volume 6 Nomor 2 Oktober 2015 


\begin{tabular}{|c|c|c|c|c|}
\hline & & & & $\begin{array}{l}\text { kartu-kartu } \\
\text { bilangan } 2 \\
\text { digit, } \\
\text { permainan } \\
\text { kartu perkalian }\end{array}$ \\
\hline 18 & $\begin{array}{l}\text { Pola: } \\
\text { meronce } \\
\text { manik-manik }\end{array}$ & $\begin{array}{l}\text { Kinestetis, } \\
\text { natural }\end{array}$ & $\begin{array}{l}\text { Manik- } \\
\text { manik, } \\
\text { gunting, } \\
\text { benang }\end{array}$ & $\begin{array}{l}\text { Membuat } \\
\text { gelang atau } \\
\text { kalung dengan } \\
\text { pola tertentu } \\
\text { sesuai kreasi } \\
\text { peserta. }\end{array}$ \\
\hline 19 & Pengubinan & Natural, logis & $\begin{array}{l}\text { Bentuk- } \\
\text { bentuk } \\
\text { dari kertas }\end{array}$ & $\begin{array}{l}\text { Anak-anak } \\
\text { bebas memilih } \\
\text { bentuk-bentuk. } \\
\text { Kelas bawah } \\
\text { mengguna- } \\
\text { kan } 1 \text { bentuk } 2 \\
\text { warna, kelas } \\
\text { atas lebih } \\
\text { memilih } \\
\text { berbagai } \\
\text { bentuk, } \\
\text { berbagai warna }\end{array}$ \\
\hline 20 & $\begin{array}{l}\text { Membuat } \\
\text { poster }\end{array}$ & Spasial & $\begin{array}{l}\text { Kertas } \\
\text { gambar, } \\
\text { spidol, } \\
\text { pensil, } \\
\text { warna, } \\
\text { krayon }\end{array}$ & $\begin{array}{l}\text { Temanya: } \\
\text { belajar } \\
\text { matematika. } \\
\text { Muncul } \\
\text { berbagai } \\
\text { macam poster: } \\
\text { misalnya Ayo } \\
\text { belajar } \\
\text { matematika }\end{array}$ \\
\hline
\end{tabular}

\section{Deskripsi math advanture: to Adisucipto}

Kegiatan ini dipersiapkan dengan sangat detail, mulai dari mengirimkan surat untuk mendapat tanda ijin dari orangtua, lalu kesediaan infak minimal 2 ribu. Peserta dibagi menjadi beberapa kelompok yang didampingi kakak mahasiswa. Berangkat dengan 2 bus berkapasitas 40-50 penumpang, perjalanan ditempuh dengan nyaman. Sesampai di lokasi, langsung menuju ruang pandang dan menyerahkan 
surat pengantar kunjungan berisi berapa peserta berapa guru. Setelah 30 menit melihat pesawat take off dan landing, lalu kelompok menyebar ke pos money changer, roti ' 0 , dan informasi secara bergantian memutar/lukir sehingga waktu kunjungan efektif

\section{Deskripsi math advanture: to Jakarta by plane and train}

Awalnya dipilih 2 peserta utama dan 2 cadangan. Ketika harga tiket memungkinkan pembelian untuk 4 peserta maka diputuskan ke 4 peserta bisa berangkat semua ke Jakarta. Subuh tanggal 10 November 2015 bertepatan dengan hari pahlawan, berlima diantar keluarga berangkat ke bandara. Setelah berfoto bersama pengantar, lalu masuk menuju chek in dan X-ray kemudian ke ruang tunggu. Menikmati penerbangan pertamanya anak-anak nampak antusias. Diiringi minum minuman ringan di penerbangan dan mengisi LKS sambil melihat awan, menjadi pengalaman berkesan tak terlupakan bagi peserta. Sesampai di terminal 3 bandara Soekarno Hatta, kemudian menikmati kue dan minuman choco fresh dan white choco di J.Co sambil mengisi LKS. Kemudian naik bus Damri menuju Gambir untuk pergi ke MK. Sesampai di MK kemudian makan siang, minum dan solat Duhur lalu mengunjungi museum MK. Dilanjutkan kemudian menuju museum Nasional, mengelilingi Jakarta dengan bus tingkat gratis, ke Istiqlal dan Monas.

\section{Desain Pembelajaran Matematika dengan pendekatan Multiple Intelligences}

a. Pertemuan ke 1,2,5,8, 9, 11, 12, 16, 19 dan 20 diampu oleh ibu Luluk Mauluah meliputi materi bilangan pada: 1,2,5 lalu geometri pada pertemuan 9 dan 11 serta 19. Adapun materi statistik pada pertemuan 12. Sepuluh pertemuan $2,4,6,7,10,13,14,15,17$ dan 18 yang diampu oleh ibu Endang Sulistyowati lebih menekankan pengalaman belajar matematika di luar kebiasaan belajar di sekolah. Istilahnya bermain matematikanya berbeda dengan di sekolah, memberikan pengalaman baru, permainan baru dan pengetahuan baru meliputi: kurva, sudoku, tangram, poster, ular angka, titik berat dan lain-lain.

b. Pertemuan ke 16 berupa petualangan matematika ke bandara Adisucipto memberikan semangat dan wawasan matematika maupun ketrampilan hidup yaitu kecerdasan intrapersonl maupun 
interpersonal. Mengenal diri: apakah mabukan atau tidak, memilih bekal kesenangannya, maupun berkelompok berdiskusi membagi tugas sangat memfasilitasi peserta untuk saling berbagi. Juga saat membeli roti ' 0 , berlima sampai bertuju hanya diberi uang 20.000 rupiah mendapat 2 buah roti dibagi bersama. Pembelajaran konversi uang rupiah ke mata uang asing juga dinikmati dengan gembira. Tiap kelompok mendapat bagian 100.000 rupiah untuk ditukarkan. Ada yang menukar ke dollar Amerika seharga 13.675 sehingga memperoleh 7 dollar dengan kembalian 4.275. Ada yang menukarkan ke riyal Arab Saudi, menukar ke ringgit Malaysia dan juga mendapat 10 dollar Singapura. Pada konter informasi anak-anak belajar bermental matematika: teliti, logis, runtut menanyakan berbagai hal misal tentang keberangkatan paling awal, paling akhir, banyaknya penerbangan, dan sebagainya.

c. Pertemuan ke 20 yaitu math adventure ke Jakarta dengan naik pesawat. Pada kegiatan ini tujuannya lebih kepada memberikan inspirasi, motivasi dan bukti bahwa peserta boleh bermimpi dan bercita-cita tinggi, bahkan hal yang jauh dari bayangan atau kurang masuk akal. Program ini ingin memberikan benih harapan agar peserta terus bersemangat belajar dan meraih hal-hal hebat di masa depannya.

\section{Simpulan}

1. Desain pembelajaran matematika dengan pendekatan multiple intelligences untuk siswa SD/MI di Bantul terdiri dari 18 pertemuan les gratis dengan bermain dan peraga berbasis multiple intelligences yaitu dengan musik, dengan gerak/aktifitas fisik, menggunakan berbagai peraga: buah-buahan, sereal, gela ukur, praktek, dan lain-lain. Dua pertemuan berupa kegiatan unggulan yaitu math adventure to Adisucipto dan math adventure to Jakarta, lebih memberikan wawasan kecerdasan bertahan hidup dan bermental matematika. Yaitu menggunakan matematika dalam kehidupan nyata.

2. Berdasarkan observasi, wawancara dan angket, lebih dari $85 \%$ yaitu 35 dari 40 peserta sangat menyukai pelaksanaan pembelajaran matematika berbasis multiple intelligences dengan peraga, permainan dan aktivitas serta adventure. 


\section{DAFTAR PUSTAKA}

Erman Suherman dkk, Strategi Pembelajaran Matematika Kontemporer, Bandung: UPI, 2003

Kezar, Theory of Multiple Intelligences: Implication for Hegher Education, Innovative Education, vol 26, No 2, Winter, 2001

Marsigit, Pengembangan Karakter dalam Pendidikan Matematika (Pendidikan Karakter dalam Perspektif Teori dan Praktek),Yogyakarta: UNY Press, 2011

Muhammad Yaumi, Pembelajaran Berbasis Multiple Intelligences, Jakarta: Dian Rakyat, 2012

Nurul Zuriah, Pendidikan Moral dan Budi Pekerti dalam Perspektif Perubahan, Jakarta: Bumi Aksara, 2007

Sonawat and Gogri, Multiple Intelligences for Preschool Children; Mumbai: Multi-Tech Publishing co, 2008

Tengku Zahara Djafar, Kontribusi Strategi Pembelajaran Terhadap Hasil Belajar. Jakarta: Balitbang Depdiknas, 2001

Thomas Armstrong, Setiap anak cerdas Panduan membantu anak belajar dengan memanfaatkan multiple intelligence, USA: ASCD, 2005 